\title{
Wild-type p53 negatively regulates the expression of a microtubule-associated protein
}

\author{
Maureen Murphy, Adrian Hinman, and Arnold J. Levine ${ }^{1}$ \\ Department of Molecular Biology, Princeton University, Princeton, New Jersey 08544 USA
}

\begin{abstract}
The product of the p53 tumor suppressor gene has a well-documented activity as a transcriptional activator, and several studies indicate that this function is at least in part essential for the ability of p53 to suppress cellular proliferation. However, there is growing evidence that some activities of wild-type p53 may be independent of its trans-activation function; in fact, recent investigations have indicated that the transcriptional repression function of $\mathbf{p 5 3}$, rather than its trans-activation function, may be influential in p53-mediated apoptosis. The focus of this study has been on the identification of genes that exhibit decreased expression during p53-dependent apoptosis, and therefore represent potential p53-repressed genes influential in programmed cell death. This report identifies the gene encoding the microtubule-associated protein MAP4 as one whose mRNA and protein expression decrease in cells following induction of wild-type p53. Importantly, decreased MAP4 expression following p53 induction can be inhibited by molecules that prevent p53-mediated transcriptional repression and apoptosis, such as the adenovirus E1B-19K protein and the Wilms tumor gene product WT1. Additionally, overexpression of MAP4 in cells induced to undergo p53-dependent apoptosis significantly delays this process, indicating that the negative regulation of this gene by p53 may be influential in the rapid progression of apoptosis.
\end{abstract}

[Key Words: p53; MAP4; microtubules; apoptosis]

Received August 1, 1996; revised version accepted October 17, 1996.

The protein product of the p53 tumor suppressor gene has a well-established role in the suppression of cellular growth and transformation, as well as in the establishment and maintenance of growth arrest subsequent to DNA damaging events (for review, see Gottlieb and Oren 1996). Significantly, this gene is frequently deleted or inactivated by point mutation in diverse human cancers (Levine 1993), indicating that its activities are antagonistic to the uncontrolled cellular proliferation that is the hallmark of neoplastic growth. The best characterized function of p53 remains its ability to function as a transcriptional trans-activator, binding specifically to $\mathrm{p} 53$ response elements and activating the expression of adjacent genes. Several p53-induced genes have thus far been isolated; among the best-characterized are those encoding $\mathrm{mdm} 2$, the normal cellular regulator of p53 (Barak et al. 1993; Wu et al. 1993), GADD45 (Kastan et al. 1992), and $\mathrm{p} 21 / \mathrm{Waf} 1 / \mathrm{Cip} 1$ (El-Deiry et al. 1993). In particular, trans-activation of the latter cyclin-dependent kinase inhibitor has been shown to be partially responsible for the $\mathrm{G}_{1}$ growth arrest mediated by p53 (Deng et al. 1995). Alternatively, in some cell types induction of wild-type p53 can cause cells to undergo apoptosis; in this case, the

\footnotetext{
${ }^{1}$ Corresponding author.
}

contribution of p53-mediated trans-activation is less clear, and may be required only in certain cell types (Caelles et al. 1994; Wagner et al. 1994; Haupt et al. 1995; Sabbatini et al. 1995b).

The 553 protein has a less well characterized activity in the negative regulation of transcription. In transient assays, p53 has been shown to repress transcription driven from certain viral promoters, as well as from some cellular genes, such as PCNA and c-fos (Ginsberg et al. 1991; Seto et al. 1992; Mack et al. 1993). Significantly, recent studies indicate that the transcriptional repression function of p53 may be influential in the ability of this protein to mediate programmed cell death. Specifically, these studies indicate that proteins that inhibit p53-mediated apoptosis, such as WT-1, bcl-2, and the adenovirus E1B-19K protein, also function to inhibit the transcriptional repression function of $\mathrm{p} 53$, whereas the ability of this protein to function as a trans-activator remains unaffected (Shen and Shenk 1994; Maheswaran et al. 1995; Sabbatini et al. 1995a). Currently, however, the elucidation of the mechanism of p53-mediated repression has been hindered by the fact that $\mathrm{p} 53$-repression studies typically are performed using transient expression assays under conditions of artificial overexpression of both p53 and target promoters, where "squelching" by p53 can occur. In fact, to date, no en- 
dogenous gene whose expression is decreased following physiological induction of wild-type p53 has been identified.

In this study, the hypothesis that $\mathrm{p} 53$ functions as a transcriptional repressor as well as an activator has been tested. Experiments were designed to identify genes that are down-regulated following p53 induction, and in turn may be influential in mediating p53-dependent apoptosis. The technique of differential display (Liang and Pardee 1992) has been employed to identify cDNA clones representing genes exhibiting decreased expression following induction of wild-type p53 in a cell line that undergoes p53-mediated apoptosis. DNA sequence analysis of two of these cDNA clones revealed that one shares significant homology with the human FK506 binding protein 25 (FKBP25). Another cDNA was found to be identical to that encoding murine MAP4, a microtubule binding protein whose function is believed to involve the catalysis of microtubule polymerization. The identification of these two genes as candidate p53-repressed genes has implications for understanding the ability of p53 to mediate several diverse functions, such as apoptosis, growth arrest, and the control of cellular ploidy.

\section{Results}

mRNA levels for DD1 and DD14 are decreased at the transcriptional level during p53-dependent apoptosis and growth arrest

In order to assess the similarities and differences between p53-mediated apoptosis and growth arrest, analysis was made of the gene expression differences between the murine embryo fibroblast-derived cells lines Val5 and Vml0. The Val5 cell line was generated by transfection of the murine cell line 10.1, which contains no endogenous p53, with the temperature-sensitive $\mathrm{p} 53$ allele encoding valine at amino acid 135 (Wu et al. 1993). Culture of Val5 cells at $39^{\circ} \mathrm{C}$ results in asynchronous growth, with the majority of p53 protein in a mutant conformation; temperature shift to $32^{\circ} \mathrm{C}$ causes the majority of p53 to assume its wild-type conformation and activity, resulting in a well-characterized growth arrest in the $G_{1}$ phase of the cell cycle (Wu et al. 1993). The $\mathrm{Vm} 10$ cell line is a clonal derivative of Val 5 cells that has been stably transfected with an expression construct encoding the c-myc proto-oncogene; the establishment and characterization of this cell line has been described recently (Chen et al. 1996). Importantly, while the growth of a majority of Val5 cells is arrested in $\mathrm{G}_{1}$ at $32^{\circ} \mathrm{C}$, p53 induction in Vm 10 cells predominantly results in programmed cell death, or apoptosis. These derivative cell lines therefore serve as a useful model system for elucidating the molecular and biochemical distinctions between p53-mediated apoptosis and growth arrest.

Differential display analyses were performed on total RNA isolated from Val5 and Vml0 cells cultured at $39^{\circ} \mathrm{C}$, and after temperature shift to $32^{\circ} \mathrm{C}$ (and wild-type p53 induction) for 8 and $30 \mathrm{hr}$. At these temperatureshift time points, the number of Vm10 cells demonstrat- ing morphological indicators of apoptosis, such as cellular rounding up and chromatin condensation, is $\sim 15 \%$ and $80 \%$, respectively (data not shown). These analyses revealed the existence of several cDNA species exhibiting increased expression at $32^{\circ} \mathrm{C}$, and fewer cDNAs exhibiting decreased expression at this temperature, in both cell lines (data not shown). However, there was no evidence for the existence of cDNAs that were up- or down-regulated specifically during growth arrest or apoptosis; rather, the gene expression profiles of these two cell lines at $32^{\circ} \mathrm{C}$ were indistinguishable from each other (data not shown). Because of the implied relationship between p53-mediated transcriptional repression and apoptosis, focus was placed on the identification of genes exhibiting decreased expression following p53 induction.

Two of the down-regulated cDNA species identified and isolated from these studies, termed DDI and DD14, were cloned and used for RNase protection in $\mathrm{Vm} 10$ and its parental cell line, Val5, which undergoes p53-mediated $G_{1}$ growth arrest at the permissive temperature. The level of expression of DD1 message is decreased $\sim 75 \%$ and $95 \%$ in $\mathrm{Vm} 10$ cells after temperature shift to $32^{\circ} \mathrm{C}$ for 8 and $30 \mathrm{hr}$, respectively (Fig. 1A, lanes 2-4). Similarly, the level of DD14 message is decreased $\sim 65 \%$ and $95 \%$ following temperature shift for these time points (lanes 5-7). Similar decreases occurred in growtharrested Val5 cells (data not shown). In contrast, the mRNA levels for $\beta$-actin remained constant in these cells (Fig. 1A, $\beta$-actin), as did that of several other genes tested, such as glyceraldehyde-6-phosphate-dehydrogenase (GAPDH; data not shown). RNase protection of DD1 and DD14 in 10.1 cells indicated that there were no alterations in these mRNA levels following temperature shift; therefore, the decreased expression of this gene was not the result of temperature shift alone /data not shown). Sequence analysis of the DD1 cDNA clone and comparison with sequences in the GenBank data base revealed homology to the gene encoding human FK506 binding protein 25 (data not shown). DD14 demonstrated nearly $100 \%$ homology with the $3^{\prime}$ untranslated region of the gene encoding murine MAP4 (microtubule-associated-protein 4) (data not shown).

In an effort to determine whether decreases in DD1 and Map4 mRNA levels following p53 induction occurred at the transcriptional or post-transcriptional level, nuclear run-on assays were performed. Figure 1B depicts data from nuclear run-on transcription assays performed on nuclei isolated from Val 5 cells cultured at $39^{\circ} \mathrm{C}$, and following temperature shift to $32^{\circ} \mathrm{C}$ for $24 \mathrm{hr}$. As evident in the figure, following temperature shift to $32^{\circ} \mathrm{C}$, the rate of transcription from the cellular promoter for GAPDH is not significantly altered, whereas that from the Map4 promoter is decreased $\sim 56 \%$, and that from the DDl promoter decreases $60 \%$. In contrast, the rate of transcription from the mdm2 gene, a p53 positively regulated gene, increases $\sim 400 \%$. Therefore, at least part of the negative regulation of DD1 and Map4 following p53 induction occurs via a decrease of transcription from the promoters of these genes. Because of its potentially widespread and interesting effects, focus 
A

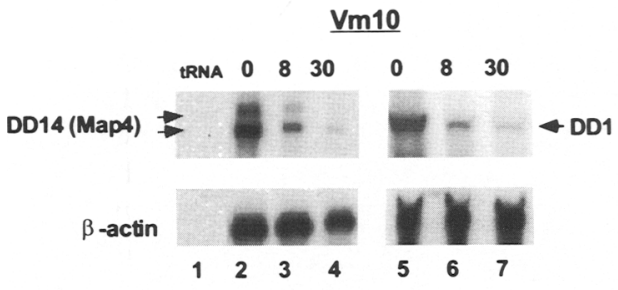

B

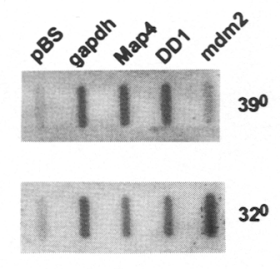

C

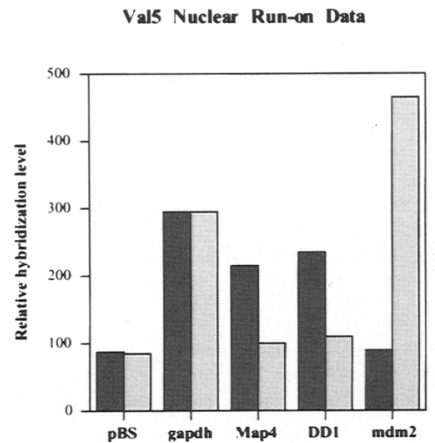

Figure 1. Temperature shift induces decreased DD1 and DD14 (Map4) RNA levels in cell lines with temperature-sensitive p53. (A) RNase protection of DD1, DD14 (Map4), and $\beta$-actin mRNA in Vm10 cells grown at $39^{\circ} \mathrm{C}$ (lanes 2 and 5, respectively) and following temperature shift-mediated induction of wild-type $\mathrm{p} 53$ at $32^{\circ} \mathrm{C}$ for 8 (lanes 3 and 6) and $30 \mathrm{hr}$ (lanes 4 and 7). The Map4 mRNA utilizes two distinct polyadenylation sites, and the Map4 cDNA used for RNA probe generation represents the smaller of these two polyadenylated forms; this probe routinely detects two different protected species, representing both polyadenylated forms of Map4 mRNA. Yeast tRNA is included instead of total RNA as a negative control (lane 1). (B) Nuclear run-on analysis using [ $\left.{ }^{32} \mathrm{P}\right] \mathrm{UTP}$-labeled nuclei from Val5 cells grown at $39^{\circ} \mathrm{C}$ (top panel) or following temperature shift to $32^{\circ} \mathrm{C}$ for $24 \mathrm{hr}$ (bottom panel). Filters contain $10 \mu \mathrm{g}$ of plasmids encoding a negative control (pBluescript SK - ), murine GAPDH, plasmid K042 encoding full-length Map4 cDNA, DD1, and full-length murine mdm2. $(\mathrm{C}\rangle$ Quantitation of nuclear nun-on data from Val5 nuclei harvested from cells grown at $39^{\circ} \mathrm{C}$ (dark gray bars) and after temperature shift to $32^{\circ} \mathrm{C}$ (light gray bars). The data shown represent the average values from two independent run-on experiments following normalization to GAPDH levels, except for the mdm2 data, which is from a single experiment.

was placed on the investigation of the nature and consequences of the negative regulation of Map4 following p53 induction.

\section{MAP4 mRNA levels are decreased during physiological induction of p53}

To determine whether reduction of the steady-state level of Map4 message occurs during physiological induction of p53, RNase protection was again employed. For these studies, cells that contain wild-type p53/the murine mammary tumor cell line C127), or are null for p53 (10.1), were treated with UV irradiation; Map4 mRNA levels were analyzed at several time points following irradiation. Treatment of $\mathrm{C} 127$ cells with $10 \mathrm{~J} / \mathrm{m}^{2}$ of $\mathrm{UV}$ irradiation resulted in consistent and stepwise decreases in Map4 transcript levels as determined by RNase protection, whereas $\beta$-actin expression remained constant (Fig. 2A). In contrast, no alterations in Map4 levels were seen following UV irradiation of 10.1 cells (null for p53) (Fig. 2B). The average results from two independent RNase protection experiments indicate that Map4 mRNA levels are $\sim 90 \%$ reduced in C127 cells $24 \mathrm{hr}$ following UV treatment, but remain unchanged in cells lacking p53 (data not shown). Similar reductions in Map4 message levels were also detected in Balb c/3T3 cells, which contain wild-type p53, following treatment with UV radiation (data not shown).

In an effort to identify the domains of the $\mathrm{p} 53$ protein necessary for mediating Map4 down-regulation, RNase protection of Map4 mRNA was performed on several murine cell lines containing derivatives of the temperature-sensitive p53 allele valine135. The cell line 10.1 Val5 25/26 contains the stably integrated p53 mutant cDNA valine135/ser25/arg26. This mutant is equiva- lent to the human $22 / 23$ mutant, and is incapable of transcriptional activity on endogenous p53-responsive genes because it contains a defective trans-activation domain (Lin et al. 1994; J. Lin and A.J. Levine, unpubl.). The results of this experiment show that this mutant is also incapable of causing decreased levels of Map4 message following temperature shift (Fig. 3, lanes 1 and 2). C18 cells contain the temperature-sensitive p53 allele

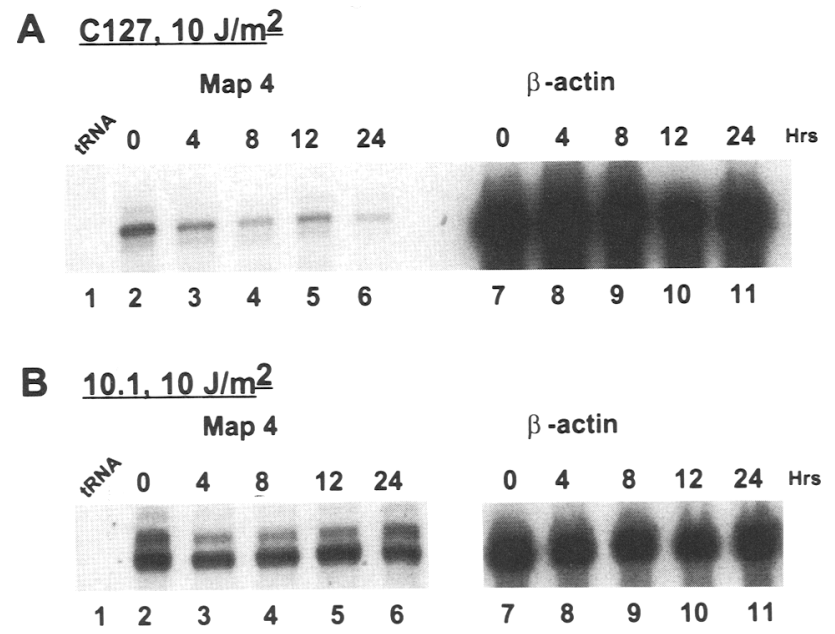

Figure 2. Physiologic induction of wild-type p53 by UV irradiation results in decreased Map4 RNA levels. $(A, B)$ RNase protection analysis of Map4 and $\beta$-actin mRNA levels in murine C127 cells, which contain wild-type p53 $(A)$, and 10.1 cells, which are null for $\mathrm{p} 53(B)$, following treatment with $10 \mathrm{~J} / \mathrm{m}^{2}$ of UV irradiation. Total RNA was collected and analyzed after 0,4 , 8,12 , and $24 \mathrm{hr}$ following irradiation; yeast tRNA was included instead of total RNA as a negative control. 


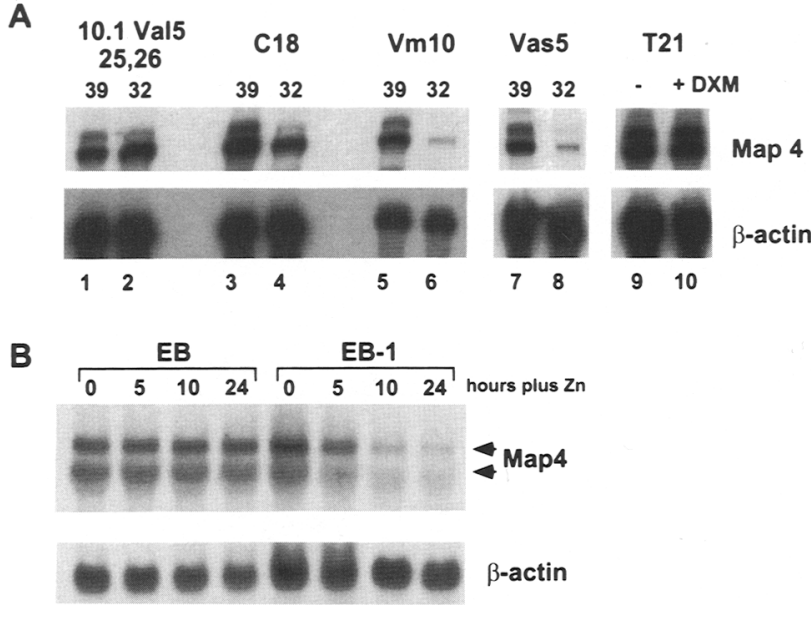

Figure 3. Decreased expression of Map4 mRNA requires murine p53 codons 25 and 26, does not occur during p53-independent apoptosis, and is conserved in human cells. $(A)$ RNase protection analysis of Map4 and $\beta$-actin levels in several murine cell lines grown at $39^{\circ} \mathrm{C}$ (lanes $1,3,5$, and 7$)$, and following temperature shift to $32^{\circ} \mathrm{C}$ for $24 \mathrm{hr}$ (lanes 2,4,6, and 8). All cell lines contain temperature-sensitive p53, and are assayed at $39^{\circ} \mathrm{C}(\mathrm{mu}$ tant conformation) and $32^{\circ} \mathrm{C}$ (the permissive temperature) with the exception of $\mathrm{T} 21$; these cells were maintained at $39^{\circ} \mathrm{C}$ and treated with $1.0 \mu \mathrm{M}$ dexamethasone for $24 \mathrm{hr}$ to induce p53independent apoptosis. $(B)$ Northern analysis of Map4 message levels in the cell line EB-1, a human colorectal carcinoma cell line with a stably transfected zinc-inducible p 53 gene, as well as the parental cell line EB, which contains no p53. Cells were treated with $0.1 \mathrm{mM} \mathrm{ZnCl}_{2}$ for the indicated times; $\beta$-actin is shown as a control for loading.

valine 135 coupled with a constitutively overexpressed E2F-1 gene. These cells, like Vm10 cells, undergo apoptosis at the permissive temperature $(\mathrm{Wu}$ and Levine 1994), and likewise demonstrate decreased Map4 expression following p53 induction (Fig. 3, lanes 3-6). Similarly, temperature shift of the cell line Vas5, which contains the temperature-sensitive alternative splice form of murine p53 (valine 135-AS; Bayle et al. 1995), also induces decreased Map4 mRNA levels following p53 induction (lanes 7 and 8).

An analysis was also carried out with the murine cell line T21. This line is derived from a T-cell lymphoma, and contains only mutant $\mathrm{p} 53$ (data not shown). Treatment of T21 cells with the glucocorticoid analog dexamethasone induces a rapid and uniform entry into apoptosis, as determined by nuclear morphology and DNA ladder formation (data not shown). RNase protection of Map4 mRNA in dexamethasone-treated T21 cells indicates that this form of p53-independent apoptosis is not accompanied by decreases in steady-state MAP4 message levels (see lanes 9 and 10). Finally, analysis of the human colon carcinoma EB-1, which contains a metalinducible p53 gene, demonstrates that treatment with $\mathrm{ZnCl}_{2}$ (Shaw et al. 1992) causes stepwise decreases in Map4 mRNA levels following p53 induction. In contrast, parental EB cells (no p53) exhibit no such changes fol- lowing identical treatment (Fig. 3B). Taken together, these data indicate that decreased Map4 mRNA levels occur during both p53-mediated growth arrest and apoptosis and require an intact trans-activation domain, and this also occurs in the human EB-1 cell system. However, down-regulation of this gene may well be limited to a pathway of apoptosis that is p53-dependent.

\section{Negative regulation of Map4 by $p 53$ is inhibited by E1B-19K and WT1 proteins}

It has been reported that coexpression of the adenovirus E1B-19K protein can inhibit the transcriptional repression ability of p53 in transient expression assays (Shen and Shenk 1994; Sabbatini et al. 1995a). These findings prompted an examination of the effect of this adenoviral protein on the ability of p53 to mediate Map4 mRNA decreases in stable cell lines. The $10 \mathrm{VmH}$ cell line is a 10.1-derived line that contains a stably transfected temperature-sensitive p53 mutant valine 135 , as well as a constitutively expressed c-myc gene. Like Vm10 cells, these cells undergo apoptosis in response to p53 induction at $32^{\circ} \mathrm{C}$ (X. Wu and A.J. Levine, unpubl.). Unlike $\mathrm{Vm} 10$ cells, however, $10 \mathrm{VmH}$ cells contain both p53 and c-myc on the same expression vector, which contains a selectable marker for hygromycin resistance; therefore, this line is particularly useful for further transfection studies.

$10 \mathrm{VmH}$ cells were stably transfected with an expression construct for the E1B-19K gene driven by the cytomegalovirus immediate-early promoter and conferring neomycin resistance $(10 \mathrm{VmH}-\mathrm{C})$ or with vector alone (10VmH-A). Several stable neomycin-resistant subclones of both lines were isolated. Importantly, whereas $10 \mathrm{VmH}-\mathrm{A}$ cells (vector alone) undergo apoptosis upon temperature shift to $32^{\circ} \mathrm{C}$, independent subclones of $10 \mathrm{VmH}-\mathrm{C}$ cells (E1B-19K protein) were consistently protected from apoptosis, and instead exhibit growth arrest at this temperature, as demonstrated by flow cytometry of cells stained with propidium iodide (data not shown). This result is consistent with data indicating that the E1B-19K protein inhibits p53-induced apoptosis, but not growth arrest (Sabbatini et al. 1995a). RNase protection analysis of Map4 mRNA in 10VmH-A cells /vector alone) indicates that these cells consistently exhibit decreased Map4 message levels following temperature shift (Fig. 4A, lanes 1 and 2). In contrast, both pooled (lane 4) and independent subclones of $10 \mathrm{VmH}-\mathrm{C}$ cells (with E1B$19 \mathrm{~K}$ protein) (lanes 6 and 8) failed to exhibit any decrease in Map4 mRNA following wild-type p53 induction.

As is the case with bcl-2 and E1B-19K, coexpression of the Wilms tumor gene WT-1 can inhibit p53-mediated apoptosis, as well as p53-mediated transcriptional repression, as measured in transient assays (Maheswaran et al. 1995). Two independent clones of $10 \mathrm{VmH}$ cells (temperature-sensitive p53 plus cytomegalovirus (CMV)c-myc) stably transfected with the WT-1 tumor suppressor gene were generated; these subclones were confirmed to express the WT1 gene at the RNA and protein levels (data not shown). Significantly, like E1B-19K, cell lines 
A

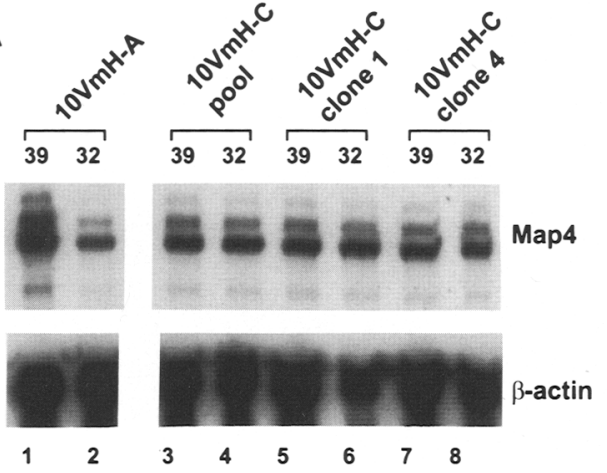

B

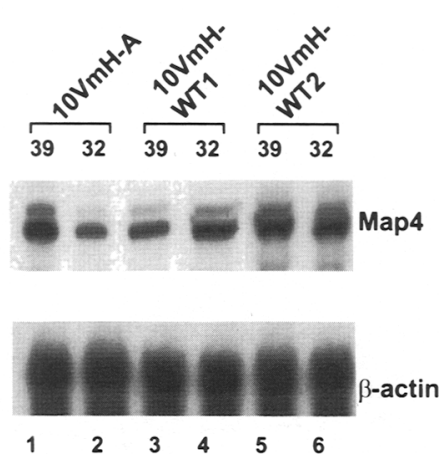

Figure 4. Decreased Map4 expression following p53 induction is blocked by expression of E1B-19K protein and WT1. RNase protection analysis of Map4 and $\beta$-actin levels in $10 \mathrm{VmH}$ cells stably transfected with $\mathrm{CMV}$-vector alone $(10 \mathrm{VmH}-\mathrm{A})$, or with expression constructs encoding E1B$19 \mathrm{~K}(10 \mathrm{VmH}-\mathrm{C})$ or the full-length Wilms tumor suppressor gene cDNA $(10 \mathrm{VmH}$ WT1 and -WT2). Total RNA was isolated and analyzed following temperature shift to $32^{\circ} \mathrm{C}$ for $24 \mathrm{hr}$. Stably transfected independent subclones expressing E1B-19K (clones 1 and 4) and WT1 (clones WT1 and WT2) were analyzed, except for lanes 3 and 4, in which pooled G418-resistant clones transfected with E1B-19K were analyzed. stably expressing the WT1 gene failed to demonstrate Map4 mRNA decreases following wild-type p53 induction (Fig. 4B, lanes 4 and 6). On the other hand, several independent $10 \mathrm{VmH}$ subclones transfected with the parental vector alone consistently demonstrated Map4 decreases at the permissive temperature (Fig. 4B, lanes 1 and 2, and data not shown). Therefore, E1B-19K and WT1 proteins, both of which selectively target and inhibit p53-mediated transcriptional repression in transient assays, can also prevent the decreased expression of the endogenous Map4 gene following p53 induction in these stable cell lines.

MAP4 organization is rapidly altered during p53-mediated apoptosis, but not during p53-mediated growth arrest

In order to elucidate the nature of MAP4 alterations at the protein level, both Western and immunofluorescence analyses were performed on Vmlo and Val5 cells following temperature shift using antisera generated against the MAP4 protein. As shown in Figure 5, steadystate levels of MAP4 protein are decreased in Vm10 cells following temperature shift to $32^{\circ} \mathrm{C}$ (lanes 1-3). Nearly

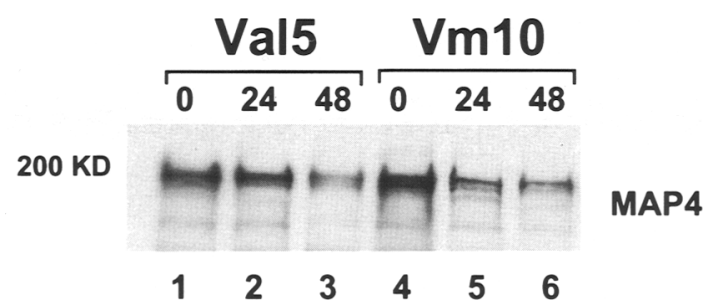

Figure 5. MAP4 protein levels are decreased following p53 induction in Vm 10 and Val5 cells. Immunoprecipitation-Western analysis of MAP4 protein levels in Vm10 and Val5 cells grown at $39^{\circ} \mathrm{C}$, and after temperature shift and wild-type p53 induction at $32^{\circ} \mathrm{C}$ for 24 and $48 \mathrm{hr}$. Equal amounts of protein were precipitated with polyclonal antisera directed against murine Map4, followed by Western analysis using IF5 MAP4 monoclonal. identical decreases in MAP4 protein levels were detected in Val5 cells following temperature shift (lanes 4-6). There was, however, no significant decrease in the steady-state level of $\beta$-tubulin following temperature shift, nor were MAP4 protein levels altered by temperature shift in 10.1 cells (data not shown).

Somewhat surprisingly, immunofluorescence of MAP4 protein revealed that the organization of this protein is altered dramatically in Vm 10 cells, but not Val5 cells, very shortly following p53 induction. As shown in Figure 6, in both $\mathrm{Vm} 10$ and Val5 cells cultured at $39^{\circ} \mathrm{C}$, MAP4 protein is organized in a filamentous pattern, and colocalizes with the mitotic spindle in cells undergoing mitosis (panels A and D; see arrows). Double-labeling experiments indicate that this pattern is indistinguishable from $\beta$-tubulin (data not shown). Temperature shift to $32^{\circ} \mathrm{C}$ is accompanied by a rapid decrease in both the fluorescence intensity and organization of MAP4 protein in Vml0 cells, which are programmed to undergo apoptosis. Four hours following temperature shift to $32^{\circ} \mathrm{C}$, the fluorescence intensity of this protein is greatly diminished, and after $24 \mathrm{hr}$ this protein is virtually undetectable (Fig. 6, panels B and C, respectively). In contrast, MAP4 protein is only subtly altered in Val5 cells at $32^{\circ} \mathrm{C}$ (panels $\mathrm{E}$ and $\mathrm{F}$ ). 10VmH-C cells, which are protected from MAP4 decreases by the E1B-19K protein, show no alterations in MAP4 fluorescence pattern after incubation at $32^{\circ} \mathrm{C}$ for $24 \mathrm{hr}$ (data not shown). Therefore, whereas MAP4 protein and mRNA levels demonstrate similar reduction during p53-mediated growth arrest and apoptosis, changes in the organization and fluorescence intensity of MAP4 are markedly more pronounced during apoptosis, and occur more rapidly than would have been predicted based on the mRNA and Western data.

Overexpression of MAP4 in Vm10 cells delays apoptosis, as measured by the accumulation of cells with a sub-G $G_{1}$ DNA content

The combined data from immunoprecipitation and im- 
Figure 6. MAP4 fluorescence pattern is significantly altered in $\mathrm{Vm} 10$ cells, but not in Val5 cells, following p53 induction. Immunofluorescence of MAP4 protein using the IF5 monoclonal antibody directed against murine MAP4 was performed in $\mathrm{Vm} 10$ and Val5 cell lines grown at $39^{\circ} \mathrm{C}(\mathrm{A}$ and $D$, respectively) and after temperature shift to $32^{\circ} \mathrm{C}$ for $4 \mathrm{hr}(B$ and $E)$ and $24 \mathrm{hr}(C$ and $F$ ). For each cell line, normal goat serum was used instead of primary antibody as a negative control; consistently these controls demonstrated negligible staining. Arrows indicate centrosome/spindle staining.
Vm10

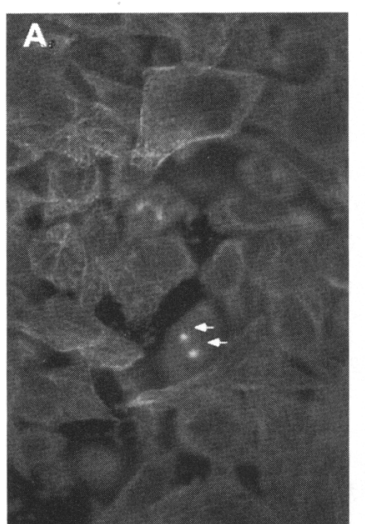

Val5

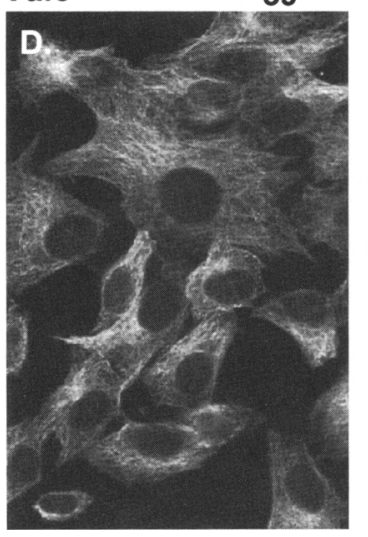

$32{ }^{\circ} 4$ hours

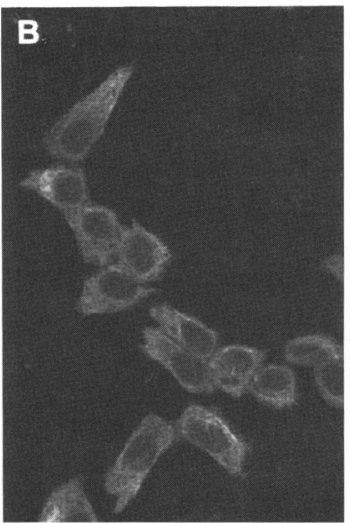

3204 hours

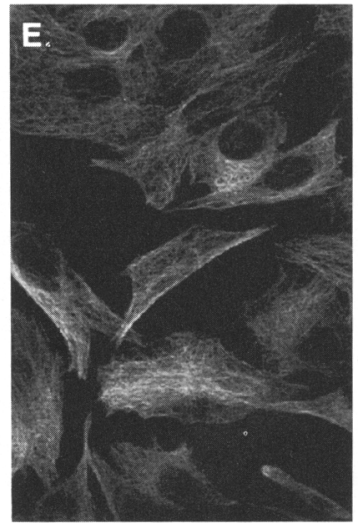

$32^{\circ} \quad 24$ hours

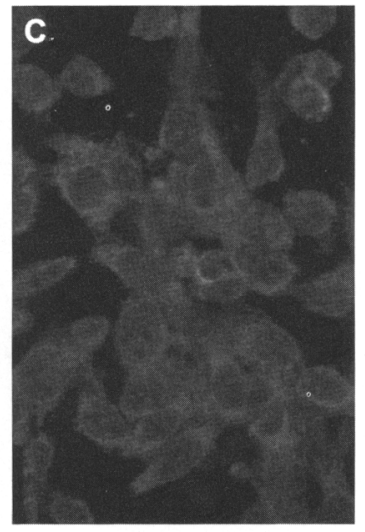

32024 hours

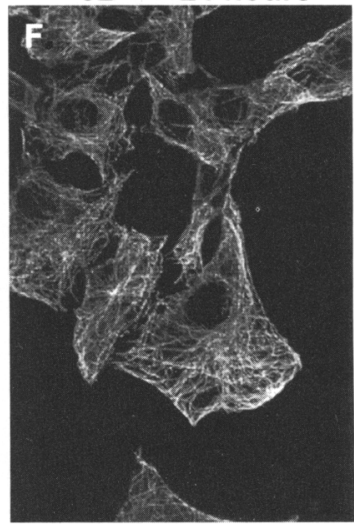

munofluorescence experiments pointed to the possibility that two levels of negative regulation of MAP4 exist in apoptotic cells; one of these is transcriptional repression following p53 induction. Additionally, however, the organization of MAP4 on microtubules also is altered dramatically during apoptosis. Immunofluorescence with tubulin antibodies indicates that, like MAP4, microtubule organization was rapidly (by $4 \mathrm{hr}$ ) altered in Vmlo apoptotic cells (data not shown), but it is unclear whether this is a cause, or an effect, of the negative regulation of MAP4. In order to explore the consequences of both of these types of negative regulation of MAP4 in the process of apoptosis, the effects of overexpression of MAP4 during apoptosis was assessed. Therefore, either CMV-Map4 or the parental vector CMVneoBam3 was transiently cotransfected into $\mathrm{Vm} 10$ cells grown at $39^{\circ} \mathrm{C}$, along with the plasmid CMV-CD20, which encodes the $B$ cell-specific membrane antigen CD20. Thirty-six hours following transfection, transfected cells were temperature-shifted to $32^{\circ} \mathrm{C}$ for 8 or $24 \mathrm{hr}$ to activate wildtype p53, and then analyzed by flow cytometry. Flow cytometric sorting of CD20-positive cells effectively allows one to sort and analyze specifically the DNA-transfected and cotransfected cell population, to then assess the effects of the transfected gene(s) (van den Heuvel and Harlow 1993). Cell staining with propidium iodide measures DNA content prior to cell sorting, and the popula- tion of cells containing a sub-G $\mathrm{G}_{1}$ DNA content, representing primarily apoptotic cells with fragmented DNA, can be quantitated and used as a measure of the ability of a population of cells to undergo apoptosis. A similar type of analysis recently has been utilized to demonstrate the protective effect of $\mathrm{mdm} 2$ on $\mathrm{p} 53$-mediated apoptosis in some cell types (Haupt et al. 1996) and on p53-mediated growth arrest in others (Chen et al. 1996).

Transient cotransfection of the parental vector, CMVneo-Bam3, with CMV-CD20 did not significantly alter the percentage of $\mathrm{Vm} 10$ cells with a sub- $\mathrm{G}_{1}$ DNA content after $24 \mathrm{hr}$ of temperature shift to $32^{\circ} \mathrm{C}$ (Fig. 7A, cf. CD20-positive vs. CD20-negative). In contrast, cells transfected with CMV-Map4 and CMV-CD20 consistently demonstrated a significantly decreased percentage of cells with a sub-G ${ }_{1}$ DNA content (Fig. 7B, CD20-positive vs. CD20-negative). The combined results from three independent transfection/flow cytometry experiments, followed by either 8 or $24 \mathrm{hr}$ of temperature shift to $32^{\circ} \mathrm{C}$, are depicted in graph format in Figure $7 \mathrm{C}$. Briefly, these data indicate that, following $24 \mathrm{hr}$ of temperature shift to $32^{\circ} \mathrm{C}$, nontransfected Vm 10 cells and vector-alone transfectants contain $35.1 \pm 3.8 \%$ and $35.45 \pm 0.25 \%$ of cells with a sub-G $\mathrm{G}_{1}$ DNA content, respectively. In contrast, Map4-transfectants contain $23 \pm 2.6 \%$ of cells in this population; the difference here is statistically significant (Student's $t$-test, $P<0.0005$ ). 
A $\mathrm{CD20+}$

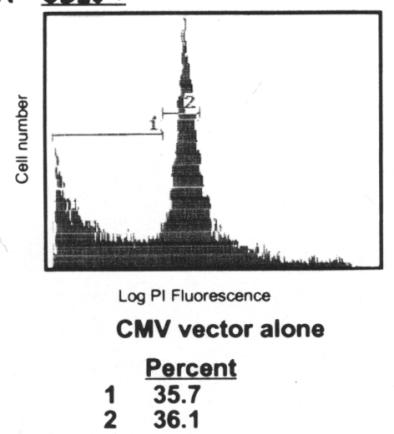

B

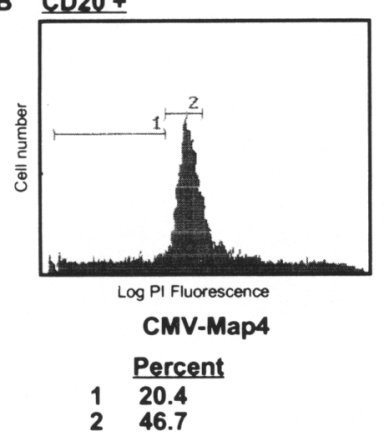

CD20:-

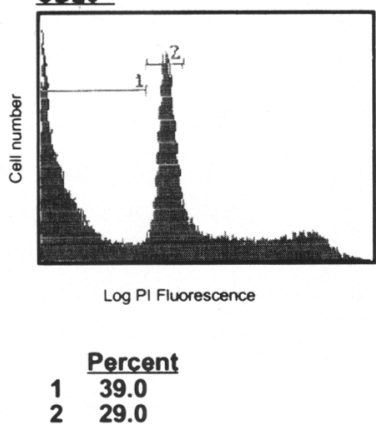

CD20 -

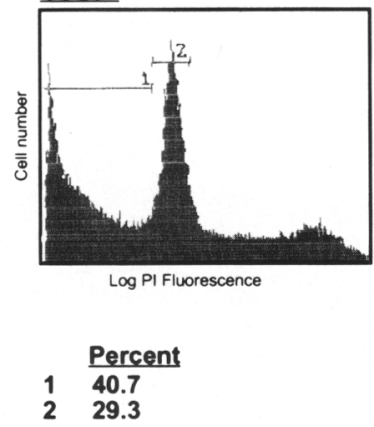

C

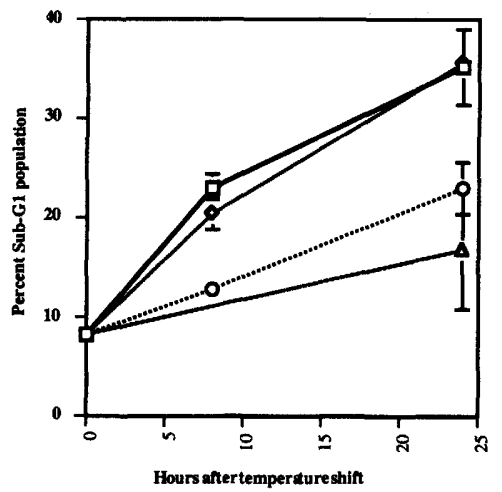

Figure 7. Transfection of the Map4 cDNA, but not parental vector alone, delays the appearance of a population of cells with a sub-G content. $(A, B)$ Vml0 cells were transfected with $20 \mu \mathrm{g}$ of CMV-neo-Bam3 $(A)$ or CMV-Map4 $(B)$ plus $4 \mu \mathrm{g}$ CMV CD20. Thirty-six hours post-transfection cells were shifted to $32^{\circ} \mathrm{C}$ for $24 \mathrm{hr}$, then harvested and stained with FITC-conjugated CD20 antibody and propidium iodide to measure DNA content. Cells positive for FITC fluorescence (transfected cells) are depicted in the left-hand panel and nontransfected cells (CD20 - ) from the same population are on the right. Log fluorescence intensity of propidium iodide is plotted on the $x$-axis, and cell number is plotted on the $y$-axis. Bar 2 quantitates the $G_{1}$ population of cells, and bar 1 quantitates the sub- $G_{1}$, or largely apoptotic, population. $(C)$ Map4 overexpression protects cells from apoptosis. Plot of the average percentages of sub-G $\mathrm{G}_{1}$ population from three independent transfection/flow cytometry experiments. Vm10 cells were transfected as above with either CMV vector alone $(\diamond), \mathrm{CMV}-\mathrm{Map} 4(\mathrm{O})$, or CMV-bcl-2 $(\Delta)$, and temperature shifted for 8 or $24 \mathrm{hr}$, except for bcl-2 transfectants, which were analyzed only after $24 \mathrm{hr}$. (미 Control. Cells were harvested and stained with FITC-conjugated anti-CD20 and propidium iodide. The value at $0 \mathrm{hr}$ reflects the average percentage of sub- $G_{1}$ cells at $24 \mathrm{hr}$ following temperature shift when cells were transfected with CMV plasmid alone, without CD20 plasmid. Error bars indicate standard deviation values from the three averaged values.

A slightly greater protection from apoptosis was seen after transfection of the bcl-2 gene (Fig. 7C).

\section{Discussion}

In this study, the technique of differential display has been used to identify genes exhibiting decreased expression following p53 induction in cells destined to undergo p53-mediated apoptosis. Although the collected data suggest that several genes exhibit differential mRNA levels following p53 induction, the overwhelming majority of genes expressed in apoptotic cells were expressed at identical levels in asynchronously growing cells. In fact, no evidence was found for wild-type p53 acting as a global repressor of generalized transcription during either growth arrest or apoptosis /data not shown). Additionally, although several cDNA clones encoding genes with reduced or enhanced expression following p53-dependent apoptosis (Vml0 cells) were successfully isolated, these genes were all regulated identically in $G_{1}$ growth arrest (Val5 cells). These data argue that transcriptional repression following p53 induction may be necessary, but not sufficient, for the induction of apoptosis. Therefore, it seems most likely that genes found subject to negative regulation during apoptosis will have a role in the execution or progression of this process, rather than the commitment or initiation.

The gene encoding Map4 has been identified as one exhibiting significant decreases at both the mRNA and protein levels following the induction of wild-type p53. During apoptosis this decrease in protein level is accompanied by what may be a post-translational alteration that causes dramatic and rapid alterations of the organization of both MAP4 and cellular microtubules. Treatment of $\mathrm{Vm} 10$ cells cultured at $39^{\circ} \mathrm{C}$ with $50 \mu \mathrm{M}$ etoposide, to induce p53-independent apoptosis, causes similar alterations in the organization of MAP4 (data not shown). Therefore, it is likely that this additional level of negative regulation is p53-independent. Significantly, data from transient transfection analyses indicate that prevention of both forms of MAP4 down-regulation (mRNA down-regulation and changes in protein organi- 
zation) by overexpression of this protein can delay the onset of phenotypic indicators of apoptosis, such as the appearance of fragmented DNA. This effect appears to be specific for apoptosis, as overexpression of MAP4 in Val5 cells does not alleviate p53-mediated growth arrest $(\mathrm{M}$. Murphy and A.J. Levine, unpubl.). These data strengthen the previously implied link between p53-mediated transcriptional repression and apoptosis.

Previous studies from several groups have provided conflicting results as to the need for p53-mediated transactivation for the process of apoptosis. Whereas some studies have found the transactivation domain of p53 to be essential for the ability of this protein to induce apoptosis (Sabbatini et al. 1995b), other studies have indicated that this domain may be dispensable for apoptosis induction (Haupt et al. 1995). It is likely that these differences are dependent on the cell type employed in each study. Experiments reported here demonstrate that the same codons critical for p53-mediated transactivation (codons 25 and 26 of murine p53) are also essential for the ability of this protein to mediate transcriptional repression of Map4. Therefore, studies that utilize mutations in this p53 domain require caution in the interpretation of results, as both transcriptional activation and repression are mediated by this domain.

MAP4 is a protein that is known to bind, polymerize, and stabilize microtubules (Olmsted 1991). Microtubule destabilization has been reported previously to be associated with the initiation or progression of apoptosis in certain cell types (Martin and Cotter 1990; Miyashita and Reed 1992). Additionally, MAP4 can also interact with actin (Maccioni and Cambiazo 1995; our unpublished observations) and catalyze the polymerization of actin monomers into filamentous actin in vitro (Maccioni and Cambiazo 1995). Therefore, decreased MAP4 levels during apoptosis may affect the rounding up and cellular collapse evident during this process, as well as the abnormal vesicle formation that occurs (Wyllie et al. 1980). An interaction between MAP4 and cyclin B recently has been established (Ookata et al. 1995), raising the interesting possibility that MAP4 alterations can affect cdc2-kinase activity or localization during apoptosis; such alterations have been reported to be influential or even causal to the apoptotic program (Shi et al. 1994).

The results presented here support the possibility that p53 is a transcriptional repressor, perhaps when it is bound with other transcription factors. Several other candidate $\mathrm{p} 53$-repressed genes have been identified previously (Miyashita et al. 1994; Zhang et al. 1996). However, the validity of these results is limited by the fact that these previous repression studies were performed in transient expression assays, where p53 is overexpressed and has strong squelching activity on many (nonphysiologically regulated) promoters. Map4 represents the first gene shown to exhibit decreased expression following the physiological induction of wild-type p53 (induced by UV irradiation). The elucidation of the mechanism whereby p53 negatively regulates the expression of this gene now awaits the cloning and characterization of the
Map4 promoter and delineation of those regions necessary to confer transcriptional repression.

\section{Materials and methods \\ Cell culture and establishment of stably transfected cell lines}

The cell lines Val5, Vm10, 10.1, C18, 10.1Val5 25/26, and Vas5 were generated and maintained as described (Wu et al. 1993; Wu and Levine 1994; Bayle et al. 1995; Sabbatini et al. 1995b; Chen et al. 1996). The 10VmH cell line was established from murine 10.1 cells transfected with a plasmid construct encoding the temperature-sensitive valine 135 p53 mutant coupled with CMV-c-myc and a hygromycin resistance gene as a selectable marker (X. Wu and A.J. Levine, unpubl.). These cells were maintained in DMEM with $10 \%$ fetal bovine serum (FBS) and 200 $\mathrm{U} / \mathrm{ml}$ hygromycin B (Calbiochem). The T21 cell line was established from a $T$-cell lymphoma from a mouse transgenic for the murine valine 135 p 53 mutant driven by the lymphotrophic papovavirus promoter/enhancer, and crossed into $\mathrm{p} 53$ knockout mice such that the mutant transgene is the only p53 allele (J. Chen and A.J. Levine, unpubl.). This line was maintained at $39^{\circ} \mathrm{C}$ in RPMI supplemented with $10 \%$ FBS and $0.05 \mathrm{~mm} \beta$-mercaptoethanol. For apoptosis induction, $50 \%$ confluent plates were incubated for $24 \mathrm{hr}$ in normal media supplemented with $1.0 \mu \mathrm{M}$ dexamethasone (Sigma). Apoptosis was monitored by nuclear morphology and DNA ladder formation, as described (Chen et al. 1996).

The cell lines $10 \mathrm{VmH}-\mathrm{A}, 10 \mathrm{VmH}-\mathrm{C}, 10 \mathrm{VmH}-\mathrm{WTl}$, and $10 \mathrm{VmH}-\mathrm{WT} 2$ were generated by stable transfection of $10 \mathrm{VmH}$ cells via Lipofectamine transfection using protocols supplied by the manufacturer (Gibco/BRL) with plasmids encoding CMVneo-Bam3, CMV-E1B-19K, and CMV-WT1 (encoding the fulllength, unspliced WT1 cDNA, provided by F. Rauscher, Wistar Institute, Philadelphia, PA), respectively. $10 \mathrm{VmH}-\mathrm{C}$ lines were confirmed to express E1B-19K at the RNA level by Northern analysis (data not shown); 10VmH-WT cell lines were confirmed to express WT1 at both the RNA and protein levels using Northern analysis and immunoprecipitation of radio-labeled cell extract with rabbit polyclonal sera generated against WT1, kindly provided by F. Rauscher.

RNA isolation, Northern and run-on analysis, differential display, cDNA cloning and sequencing, RNase protection, UV treatment

Total cellular RNA was isolated after lysis of cells in guanidine$\mathrm{HCl}$ and centrifugation on cesium chloride cushions, as described (Murphy et al. 1993). Northern blotting and hybridization was performed as described (Wu et al. 1993); for the induction of apoptosis, EB-1 cells were grown in media supplemented with $0.1 \mathrm{mM} \mathrm{ZnCl}_{2}$, as described (Shaw et al. 1992). Differential display was performed according to protocols provided by the manufacturer (GenHunter). cDNA clones isolated from polymerase chain reaction (PCR) were cloned into TA vector (Invitrogen) and sequenced using Sequenase V.2 as per the supplier (US Biochemical). The DD14 cDNA represents base pairs 50435297 of murine Map4 (numbering is as per MusMap4a GenBank entry|. The sequence of DD1 has been submitted to the GenBank data base, under accession no. U62545.

RNase protection was performed on independently derived RNA samples generated at least in triplicate using RNA probes generated by in vitro transcription in the presence of $\left[\alpha-{ }^{32} \mathrm{P}\right] \mathrm{UTP}$ $(10 \mu \mathrm{Ci} / \mu \mathrm{l}, \mathrm{NEN})$ using protocols derived from the manufacturer (MAXIscript, RPA II, Ambion). For UV treatment, media 
was removed from asynchronously growing $\mathrm{C} 127, \mathrm{~A} 31$, or 10.1 cells and cells were irradiated for $5 \mathrm{sec}$ with a germicidal lamp that delivered $2 \mathrm{~J} / \mathrm{m}^{2} /$ per sec; cells were isolated $0,4,8,12$, and $24 \mathrm{hr}$ following irradiation, and RNA was isolated and analyzed as described previously. Nuclear run-on analysis was performed essentially as described (Ausubel et al. 1994), except that $7.5 \times 10^{6}$ nuclei were labeled with $15 \mu \mathrm{Ci}$ of $\left[\alpha{ }^{32} \mathrm{P}\right] \mathrm{UTP}$ (NEN). Filters were washed $2 \times 1 \mathrm{hr}$ at $65^{\circ} \mathrm{C}$ in $2 \times \mathrm{SSC}$, and $1 \times 1 \mathrm{hr}$ in $1 \times \mathrm{SSC}$ with $10 \mu \mathrm{g} / \mathrm{ml}$ RNase A at $37^{\circ} \mathrm{C}$. Quantitation of signal was perfomed on a PhosphorImager (Molecular Diagnostics).

\section{Antibody generation, Western blotting, immunofluorescence}

Nucleotides 1195-2655 of the full-length murine Map4 cDNA (numbering is as per the GenBank submission MusMap4a) were cloned into the SmaI site of pGEX-3X (Pharmacia), and GST fusion proteins were synthesized and purified on glutathioneSepharose (Pharmacia) as described (Frangioni and Neel 1993) and used to generate rabbit polyclonal antisera, as described (Harlow and Lane 1988). Immunoprecipitation-Western analysis was performed as described (Del Sal et al. 1996).

Immunofluorescence was performed as described (Harlow and Lane 1988) using IF5 rat-antimouse MAP4 monoclonal supernatant, or a 1:50 dilution of polyclonal rabbit-antimouse MAP4. A 1:500 dilution in phosphate-buffered saline, $1 \%$ bovine serum albumin, $0.05 \%$ Tween-20 (PBSBT) of either goatantirat biotin (Jackson) or goat-antirabbit biotin (Jackson) was used as secondary antibody, followed by a 1:1000 dilution in PBSBT of streptavidin-cy3 (Jackson). Cells were washed, mounted, and visualized as described (Harlow and Lane 1988) using a confocal microscope (BIORAD MRC600). Similar results were obtained using both antibodies.

\section{Plasmid generation, CD20/FACscan analysis}

The plasmid $\mathrm{KO} 42$, encoding full-length murine Map4 in pBluescript, was the kind gift of Joanna Olmsted (University of Rochester, NY). The NotI-ApaI full-length Map4 fragment from this plasmid was cloned directionally into pCDNA3 (Invitrogen); full-length Map4 was digested out of this plasmid using $E c o \mathrm{RV}$ and ligated to BamHI adaptors. This insert was then cloned into pCMV-neo-Bam3 (Chen et al. 1995) to generate CMV-Map4. Vm10 cells were grown to $70-80 \%$ confluence in $15-\mathrm{cm}$ plates, and were transiently transfected with $4 \mu \mathrm{g}$ of pCMV-CD20 (courtesy of Sander van den Heuvel, Massachusetts General Hospital, Boston) and $20 \mu \mathrm{g}$ of CMV-Map4, CMV-neo-Bam3, or CMV-bcl2 (kindly provided by Jerry Shen and Tom Shenk, Princeton University, NJ) using Lipofectamine, as indicated by the supplier (Gibco/BRL). Thirty-six hours following transfection, cells were shifted to $32^{\circ} \mathrm{C}$ for 8 or $24 \mathrm{hr}$, after which they were harvested and stained with fluorescein-conjugated anti-CD20 and propidium iodide, as described (van den Heuvel and Harlow 1993). Analysis of stained cells was made on an EPICS fluorescent-activated cytometer (Coulter).

\section{Acknowledgments}

The authors thank J.B. Olmsted for MAP4 monoclonal Ab IF5 and full-length Map4 cDNA, J. Shen for the CMV-bcl2 construct, Eileen White for E1B-19K cDNA, and F. Rauscher for providing the WTI cDNA and antisera. We also thank J. Chen for advice and for communicating results prior to publication, $\mathrm{X}$. Wu for providing the $10 \mathrm{VmH}$ cell line prior to publication, and Joe Goodhouse and Jerome Zawadzki for expertise at con- focal microscopy and FACScan analysis. Finally, many thanks to the members of the Levine and Shenk laboratories for helpful discussions. M.M. is supported by a fellowship from the Jane Coffin Childs Memorial Fund for Medical Research.

The publication costs of this article were defrayed in part by payment of page charges. This article must therefore be hereby marked "advertisement" in accordance with 18 USC section 1734 solely to indicate this fact.

\section{References}

Ausubel, F.M., R. Brent, R.E. Kingston, D.D. Moore, J.G. Seidman, J.A. Smith, and K. Struhl. 1994. Current protocols in molecular biology, Vol. 2. Wiley/Greene, New York, NY.

Barak, Y., T. Juven, R. Haffner, and M. Oren. 1993. mdm2 expression is induced by wild type p53 activity. EMBO J. 12: 461-468.

Bayle, J.H., B. Elenbaas, and A.J. Levine. 1995. The carboxylterminal domain of the p53 protein regulates sequence-specific DNA binding through its nonspecific nucleic acid-binding activity. Proc. Natl. Acad. Sci. 92: 5729-5733.

Caelles, C., A. Helmberg, and M. Karin. 1994. p53-dependent apoptosis in the absence of transcriptional activation of $\mathrm{p} 53$ target genes. Nature 370: 220-223.

Chen, J., I. Lin, and A.J. Levine. 1995. Regulation of transcription functions of the p53 tumor suppressor by the mdm2 oncogene. Mol. Med. 1: 142-152.

Chen, J., X. Wu, J. Lin, and A.J. Levine. 1996. Mdm-2 inhibits the G1 arrest and apoptosis functions of the p53 tumor suppressor protein. Mol. Cell. Biol. 16: 2445-2452.

Del Sal, G., M. Murphy, E.M. Ruaro, D. Lazarevic, A.J. Levine, and C. Schneider. 1996. Cyclin D1 and p21/wafl are both involved in 553 growth suppression. Oncogene 12: 177-185.

Deng, C., P. Zhang, J.W. Harper, S.J. Elledge, and P. Leder. 1995. Mice lacking $\mathrm{p} 21^{\mathrm{CIP1} / \mathrm{WAF} 1}$ undergo normal development, but are defective in Gl checkpoint control. Cell 82: 675684.

El-Deiry, W.S., T. Tokino, V.E. Velculescu, D.B. Levy, R. Parsons, J.M. Trent, D. Lin, W.E. Mercer, K.W. Kinzler, and B. Vogelstein. 1993. WAF1, a potential mediator of p53 tumor suppression. Cell 75: 817-825.

Frangioni, J.V. and B.G. Neel. 1993. Solubilization and purification of enzymatically active glutathione-S-transferase (pGEX) fusion proteins. Anal. Biochem. 210: 179-187.

Ginsberg, D., F. Mechtor, M. Yaniv, and M. Oren. 1991. Wildtype p53 can down-regulate the activity of various promoters. Proc. Natl. Acad. Sci. 88: 7605-7609.

Gottlieb, T.M. and M. Oren. 1996. p53 in growth control and neoplasia. Biochem. Biophys. Acta 1287: 77-102.

Harlow, E. and D.P. Lane. 1988. Antibodies: A laboratory manual. Cold Spring Harbor Laboratory, Cold Spring Harbor, NY.

Haupt, Y., S. Rowan, E. Shaulian, K. Vousden, and M. Oren. 1995. Induction of apoptosis in HeLa cells by transactivation-deficient p53. Genes \& Dev. 9: 2170-2183.

Haupt, Y., Y. Barak, and M. Oren. 1996. Cell-type specific inhibition of p53-mediated apoptosis by $\mathrm{mdm} 2$. EMBO $/$. 15: $1596-1606$.

Kastan, M.B., Q. Zhan, W.S. El-Deiry, F. Carrier, T. Jacks, W.V. Walsh, B.S. Plunkett, B. Vogelstein, and A.J. Fornace, Jr. 1992. A mammalian cell cycle checkpoint pathway utilizing p53 and GADD45 is defective in ataxia telangiecstasia. Cell 71: $587-597$.

Levine, A.J. 1993. The tumor suppressor genes. Annu. Rev. Biochem. 62: 623-651. 
Liang, P. and A.B. Pardee. 1992. Differential display of eukaryotic messenger RNA by means of the polymerase chain reaction. Science 257: 967-971.

Lin, J., J. Chen, B. Elenbaas, and A.J. Levine. 1994. Several hydrophobic amino acids in the p53 amino-terminal domain are required for transcriptional activation, binding to $\mathrm{mdm}-2$ and the adenovinus $5 \mathrm{E} 1 \mathrm{~B} 55-\mathrm{kD}$ protein. Genes \& Dev. 8: $1235-1246$.

Maccioni, R.B. and V. Cambiazo. 1995. Role of microtubuleassociated proteins in the control of microtubule assembly. Physiol. Rev. 75: 835-864.

Mack, D.H., J. Vartikar, J.M. Pipas, and L. Laimins. 1993. Specific repression of TATA-mediated but not initiator-mediated transcription by wild type p53. Nature 363: 281-283.

Maheswaran, S., C. Englert, P. Bennet, G. Heinrich, and D.A. Haber. 1995. The WT1 gene product stabilizes p53 and inhibits p53-mediated apoptosis. Genes \& Dev. 9: 2143-2156.

Martin, S.J. and T.G. Cotter. 1990. Disruption of microtubules induces an endogenous suicide pathway in human leukemia HL-60 cells. Cell Tissue Kinet. 23: 545-549.

Miyashita, T. and J.C. Reed. 1992. bcl-2 gene transfer increases relative resistance of $S 49.1$ and WEHI7.2 lymphoid cells to cell death and DNA fragmentation induced by glucocorticoids and multiple chemotherapeutic drugs. Cancer Res. 52: 5407-5411.

Miyashita, T., M Harigai, M. Hanada, and J.C. Reed. 1994. Identification of a p53-dependent negative response element in the bcl-2 gene. Cancer Res. 54: 3131-3135.

Murphy, M., M.J. Pykett, P. Harnish, K.D. Zang, and D.L. George. 1993. Identification and characterization of genes differentially expressed in meningiomas. Cell Growth Diff. 4: 715-722.

Olmsted, J.B. 1991. Non-motor microtubule-associated proteins. Curr. Opin. Cell Biol. 3: 52-58.

Ookata, K., S. Hisanaga, J.C. Bulinski, H. Murofushi, H. Aizawa, T. Itoh, H. Hotani, E. Okumura, K. Tachibana, and T. Kishimoto. 1995. Cyclin B interaction with microtubule-associated protein 4 (MAP4) targets p34 ${ }^{\text {cdc2 }}$ kinase to microtubules and is a potential regulator of $\mathrm{M}$-phase microtubule dynamics. J. Cell Biol. 128: 849-862.

Sabbatini, P., S.K. Chiou, L. Rao, and E. White. 1995a. Modulation of p53-mediated transcriptional repression and apoptosis by the adenovirus ElB-19K protein. Mol. Cell. Biol. 15: 1060-1070.

Sabbatini, P., J. Lin, A.J. Levine, and E. White. 1995b. Essential role for p53-mediated transcription in E1A-induced apoptosis. Genes \& Dev. 9: 2184-2192.

Seto, E., A. Usheva, G.P. Zambetti, J. Momand, N. Horikoshi, R. Weinmann, A.J. Levine, and T. Shenk. 1992. Wild-type p53 binds to the TATA-binding protein and represses transcription. Proc. Natl. Acad. Sci. 89: 12028-12032.

Shaw, P., R. Bovey, S. Tardy, R. Sahli, B. Sordat, and J. Costa. 1992. Induction of apoptosis by wild-type p53 in a human colon tumor-derived cell line. Proc. Natl. Acad. Sci. 89: 4495-4499.

Shen, Y. and T. Shenk. 1994. Relief of p53-mediated transcriptional repression by the adenovirus E1B $19-\mathrm{kDa}$ protein or the cellular bcl-2 protein. Proc. Natl. Acad. Sci. 91: 8940-8944.

Shi, L., W. Nishioka, J. Th'ng, E.M. Bradbury, D. Litchfield, and A.H. Greenberg. 1994. Premature $\mathrm{p} 34^{\mathrm{cdc} 2}$ activation required for apoptosis. Science 263: 1143-1 145.

van den Heuvel, S. and E. Harlow. 1993. Distinct roles for cyclin-dependent kinases in cell cycle control. Science 262: 2050-2054.

Wagner, A.J., M. Kokontis, and N. Hay. 1994. Myc-mediated apoptosis requires wild type p53 in a manner independent of cell cycle arrest and ability of p53 to induce p $21^{\text {wafl/cipl }}$. Genes \& Dev. 8: 2817-2830.

Wyllie, A.H., J.F.R. Kerr, and A.R. Currie. 1980. Cell death: The significance of apoptosis. Int. Rev. Cytol. 68: 251-306.

Wu, X. and A.J. Levine. 1994. p53 and E2F-1 cooperate to mediate apoptosis. Proc. Natl. Acad. Sci. 91: 3602-3606.

Wu, X., J.H. Bayle, D. Olson, and A.J. Levine. 1993. The p53mdm-2 autoregulatory feedback loop. Genes \& Dev. 7: 1126-1132.

Zhang, L., F. Kashanchi, Q. Zhan, S. Zhan, J.N. Brady, A.J. Fornace, P. Seth, and L.J. Helman. 1996. Regulation of Insulinlike growth factor II P3 promoter by p53: A potential mechanism for tumorigenesis. Cancer Res. 56: 1367-1373. 


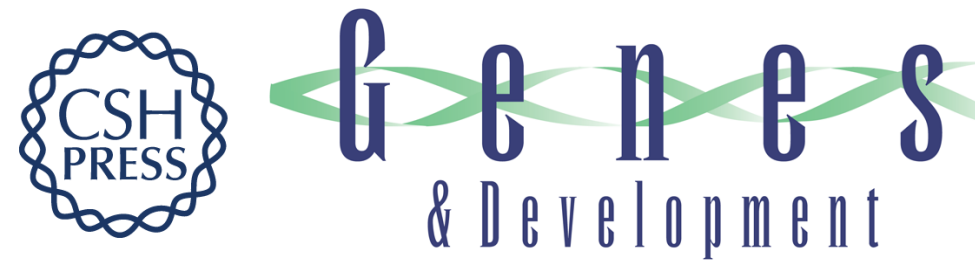

\section{Wild-type p53 negatively regulates the expression of a microtubule-associated protein.}

M Murphy, A Hinman and A J Levine

Genes Dev. 1996, 10:

Access the most recent version at doi:10.1101/gad.10.23.2971

References This article cites 38 articles, 21 of which can be accessed free at:

http://genesdev.cshlp.org/content/10/23/2971.full.html\#ref-list-1

License

Email Alerting

Service

Receive free email alerts when new articles cite this article - sign up in the box at the top right corner of the article or click here.

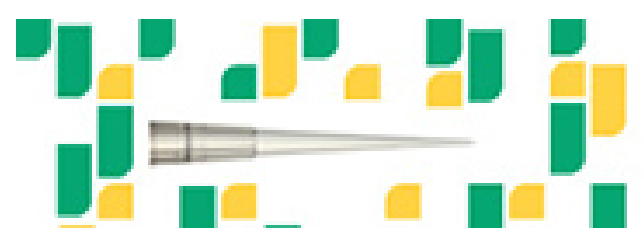

Focused on your science.

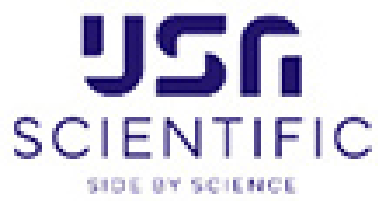

Copyright (c) Cold Spring Harbor Laboratory Press 